Article

\title{
Pricing Strategies in the Italian Retail Sector: The Case of Pasta
}

\author{
Luca Cacchiarelli * and Alessandro Sorrentino
}

Department of Economics, Engineering, Society and Business Organization (DEIM), University of Tuscia, 01100 Viterbo, Italy; sorrenti@unitus.it

* Correspondence: cacchiarelli@unitus.it

Received: 21 February 2019; Accepted: 29 March 2019; Published: 4 April 2019

\begin{abstract}
In the last years, Italian food retailing has experienced some developments related to rising concentration levels, heterogeneous distribution along the country of the different outlet categories, and an increase of products sold as private brand labels. In the Italian agro-food industry, pasta represents a strategic product, since Italy has the peculiarity of being, at the same time, the main producer and consumer of pasta. A useful way to investigate food retailers' behavior and strategies is to derive a measure of price rigidity, through a "frequency approach", which permits computation of both regular prices and price promotions, and the frequency and the magnitude of price increases and decreases. We employ such methodology in order to evaluate retailers' strategies in the Italian pasta market in terms of price rigidity and price promotions according to brand categories (Italian pasta brands versus private label brands) and regional areas for the period 2011-2013. The results show that retailers' strategies for national pasta brands, in terms of price rigidity and price promotions, are completely different with respect to private label brands. Among the various national pasta brands, retailers adopt different strategies by, in various regional cases, employing the tool of price promotion rather than intervening with regular price changes.
\end{abstract}

Keywords: retailers' price strategies; pasta; price promotions; national pasta brands; private label brands

\section{Introduction}

In the last decades, food retailing in developed countries has experienced rising concentration levels. In Italy, despite the food distribution chain presenting a lower degree of concentration than in other European countries, the industry has experienced a remarkable consolidation process over the last years. The share of total value of food sales pertaining to large retail distribution (GDO) reached $72 \%$ in 2010 (OECD 2014). The distribution of the different outlet categories is decisively heterogeneous among the various Italian regions. The north area, especially in the west, is dominated by hypermarkets, while in the central regions supermarkets prevail. The presence of small-scale stores, instead, is relevant in the southern regions, whereas hard-discount is homogeneously distributed all over the Italian territory (Banca d'Italia 2012).

Recent works have demonstrated that retail prices may vary largely as a consequence of dynamic pricing strategies on the part of retailers or manufacturers determining important consequences in the mechanism of price transmission along food supply chains (Ciapanna and Colonna 2011; Cacchiarelli et al. 2016; Cavicchioli 2018). In the face of changing supply, the price-fixing decision of the distributor may also depend on the risk, measured by the relationship between demand elasticity and variable costs, as a result of uncertainty in consumer response to price variations (Perez-Mesa et al. 2010). 
In the retailers' pricing strategy, price promotions represent an important factor of competitive dynamics in retail markets and are a key driver of retailer profitability. Pricing and promotion are often studied almost in isolation of each other, because pricing and promotion decisions are made by different managers in different departments in some retail chains (Ailawadi et al. 2009). In their strategies, retailers have to coordinate the regular prices and promotions of brands within a category, across categories, and across retail formats (Gauri et al. 2008; Bolton et al. 2007). National brands and private labels may differ in promotion effectiveness, leading to relevant implications for retailer promotion strategy. Some authors (Empen et al. 2015) have found significant empirical evidence that stronger national and international brands tend to be promoted less frequently at lower discounts compared to less renowned brands.

A way to evaluate whether the development of the modern retail affects the price distribution along the food supply chain is to consider measures of retail price rigidity (Banca d'Italia 2012). Various studies have revealed the "stickiness" of retail prices is heterogeneous across countries and products. For instance, Bils and Klenow (2004) have shown higher price rigidity in the United States than in Europe (Dhyne et al. 2006). Other authors (Verhelst and Van den Poel 2010) arrive at the reverse conclusion, indicating that regular prices appear to be far more flexible in the US data than in the European data, pointing to a more aggressive short-term pricing strategy in the US. Price changes for energy products are decisively more frequent than for food products and services, and there is higher change frequency in supermarkets than in small shops (Baudry and Sevestre 2004; Aucremanne and Dhyne 2004; Perez-Mesa et al. 2010). Moreover, significantly higher retail price rigidity is found for private label products than for nationally branded products (Müller et al. 2006). Recently, in the digital era some authors (Wang et al. 2019) have shown that in the fresh food context, the online and offline markets are of different business models. Fresh food shopping in online platforms seems to show stickier prices than those in traditional retail channels. Main factors affecting the frequency of price changes are seasonality, inflation, both at aggregate and sectoral or product-specific level, VAT rate changes, type of outlet, and, finally, the use of attractive prices (Herrmann and Moeser 2006; Dhyne et al. 2006). A work (Banca d'Italia 2012) comparing the price rigidity at the Italian retail level for olive oil, pasta, and tomatoes for 2002-2004 has shown heterogeneity across products (oil olive price changes were more frequent) and regions (Center-North presents higher price rigidity).

Pasta represents a strategic product in the Italian agro-food industry. Italy is the world's leading pasta producer, with an output worth 3.2 million tons in volume terms. This represents a quarter of worldwide output, while pasta production represents nearly $6 \%$ of total output by the Italian food industry. Italy is the largest consumer of pasta (26 kg per capita), followed by Venezuela (12.3 kg per capita) and Tunisia (11.7 kg per capita) (International Pasta Organization 2012). The Italian pasta supply chain is characterized by a high degree of concentration at processing and retailing stages. The first five largest companies present in the Italian pasta market hold about $65 \%$ of market shares, with the leader (Barilla) holding 37\% (Antitrust 2009). A case of anticompetitive practices against pasta makers has been identified and sanctioned by the Italian Antitrust Authority (Antitrust 2009; Cacchiarelli and Sorrentino 2015). Moreover, during the last twenty years, the wheat-pasta chain has been strongly affected by Common Agricultural Policy (CAP) reforms in the durum wheat sector that have progressively reduced government intervention in the market, leading to a reduction of durum wheat production in areas where it is no longer economically profitable (Cacchiarelli and Sorrentino 2018). Although pasta is a product frequently bought by Italian consumers, and while the role of branding is still very important, product label brands have recently increased their market share. Pasta, in some cases, is considered by retailers as a loss leader product, sold at a price below its market cost to stimulate other sales of more profitable goods (Chevalier et al. 2003; Kantor et al. 1997; Unionalimentari 2010).

The goal of this work is to investigate retailers' strategies in the Italian pasta market from 2011 to 2013. Specifically, price rigidity in the Italian retailing market is estimated according to brands (national pasta brands versus private label brands), different market segments, and regional areas. 
To approach such a goal, we estimate frequency, magnitude, and asymmetries in retail price changes, keeping in mind the role of promotion. Our objective is to contribute to the public debate about the role and the strategy of retailers in the Italian agro-food system through a study on their pricing behavior.

The remainder of the article is organized as follows. Section 2 investigates the factors affecting retailers' pricing strategy. Section 3 focuses on the methodology employed in the literature for investigating on price rigidity. In Section 4, the results of the estimations are discussed, while Section 5 concludes the discussion.

\section{Factors Affecting Retailers' Pricing Strategies}

Retailers' pricing decisions related to different brands and stores are often assessed in empirical research (e.g.,: Shankar and Bolton 2004) for some dimensions (price consistency of regular prices, price-promotion intensity, and relative brand prices) by analyzing relevant factors, such as brand, customer, market, store, category, and competitor characteristics. This allows researchers to assess the relative importance of brand, customer, and other determinant characteristics in retailers' pricing decisions under different conditions.

The relationship between brand loyalty and retail pricing strategies has been studied extensively in the marketing (Jing and Wen 2008; Koçaş and Bohlmann 2008, Empen et al. 2015). Designing promotion strategies involves two key decisions: the percentage reduction in price from the existing price point (depth), and the frequency with which a product is promoted. Results of the theoretical models are contradictory; for example, Agrawal (1996) predicts that retailers will promote brands with strongly brand-loyal customers more often, but with a smaller discount than weaker brands, while Raju et al. (1990) arrives at the reverse conclusion. Some empirical analyses (e.g., Empen et al. 2015) focus on two dimensions of brand loyalty: the number of loyal customers and the intensity of their loyalty. For instance, in some cases brands have a large share of loyal customers who have a low level of loyalty (they would accept only a low price increase before switching to another brands). Empen et al. (2015) found that an increased share of loyal customers leads to a more aggressive promotional price strategy. However, the higher the level of loyalty becomes, the less aggressive the pricing strategy will be. Other authors (Allender and Richards 2012) confirm that retailers promote strong brands will less discount but more frequently, compared to brands with weak loyalty. In markets where there is uncertainty about brand attributes, both prices and advertising signal brand quality. Erdem et al. (2004) found that price is an important quality signaling mechanism and that frequent price cuts can have significant adverse effects on brand equity. Moreover, the role of advertising frequency in signaling quality is also significant, but it is less quantitatively important than price.

Retailers' pricing strategies also depend on market conditions, such as concentration and competition. In the food sector, buyer power is composed of several dimensions; simply measuring the growing concentration of food processing and retailing by the number of firms or their market shares might under-estimate the potential for buyer power. For instance, Dobson and Waterson (1999) and OECD (2014) report that in some countries, the role of buyer groups increases the level of concentration in the retailing industry. Furthermore, the increase of private label adoption might represent a strategic factor that strengthen retailers' bargaining power in negotiating trade supply terms for national brands (Sorrentino Alessandro and Cacchiarelli 2018). As a consequence, some National Competition Authorities consider the degree of private label penetration as an "aggravating factor" when it comes to measuring buyer power, while, when it comes to the direct effect on consumers, there is a positive effect on prices and price competition and an increase in the variety of products. However, it might also produce possible negative effects on innovation and quality (OECD 2014).

Store characteristics (e.g., size) and category assortments at a given retail outlet also influence retailer pricing strategies (Messinger and Narasimhan 1997). Promotional elasticities are lower for categories with a larger number of brands (Narasimhan et al. 1996). 


\section{Methods}

In order to analyze the characteristics of retail price behavior across products and to derive a measure of price rigidity, two methodological approaches can be used: (i) "Duration approach", based on the interval between two price changes; (ii) "Frequency approach", based on the rate of price changes. While the former directly computes the duration for which a price remains unchanged, and only indirectly derives the frequency of price changes, the latter measures the frequency of price changes as the proportion of all prices that change in a given period. and then derives an indirect measure of price rigidity (Veronese et al. 2005; Baudry and Sevestre 2004; Banca d'Italia 2012). The main advantages of the duration approach consist of the possibility of reporting, in each period, the full distribution of price durations and of computing the hazard and survival functions. However, this approach has some weaknesses as it faces two main problems in the process of price collection: censoring (dataset truncated at the start and the finish of price changes) and attrition (the price of a product ceases to be available or an outlet has closed). The advantages of the frequency approach are the following: (i) it does not require a long span of data; (ii) in computing the average frequency of price changes, some price quotes could be easily dropped if they are considered exceptional due to a specific event (e.g., VAT change); (iii) it allows one to use the maximum amount of information from the dataset, avoiding problems linked to censored prices; (iv) finally, it can also be used to compute the frequency of price increases and price decreases for each product.

Price data in Euro per Kg are available weekly from January 2011 to December 2013 for Italy and five Italian macro regional areas. Istituto di Servizi per il Mercato Agricolo Alimentare (ISMEA) made available both regular prices and promotions for seven national brands (Garofalo, De Cecco, Voiello, Agnesi, Amato, Barilla, and Divella) and three private label brands (present across the whole Italian territory).

Based on these considerations, our choice fell on the frequency approach used often in literature (Veronese et al. 2005; Baudry and Sevestre 2004; Banca d'Italia 2012). It defines the frequency of price changes for each brand in a selected period, as follows:

$$
F_{i, j}=\frac{\sum_{t=2}^{\tau} y_{i, j, t}}{\sum_{t=2}^{\tau} x_{i, j, t}}
$$

where in the numerator we find the total number of price changes for brand $i$ sold in any outlet $j$, while, in the denominator, the total price quotes ${ }^{1}$ present for brand $i$ in any outlet $j$.

Under certain stationary conditions of the process determining price duration (Lancaster 1990; Veronese et al. 2005), the implied average duration of price for product $i$ can be computed as the inverse of the frequency of price changes:

$$
T_{i, j}=\frac{1}{F_{i, j}}
$$

where the average duration $T_{i, j}$ and the frequency of price changes $F_{i, j}$ are expressed in the same time unit (in our case week).

Furthermore, in order to evaluate retailers' behavior about price increases and price decreases for the different brands of pasta included in our dataset, we calculate their average sizes and their frequencies by employing the same method expressed, respectively, as follows:

$$
F_{i, j}^{+}=\frac{\sum_{t=2}^{\tau} y_{i, j, t}}{\sum_{t=2}^{\tau} x_{i, j, t}}
$$

1 As introduced by Baudry and Sevestre (2004), an elementary price quote Pijt is the price for product $i(i=1, \ldots, n i$, where ni is the total number of products), sold in a specific outlet $j(j=1, \ldots, n j$, where $n j$ is the total number of outlets), observed at time $t(t=1, \ldots, T)$. 


$$
F_{i, j}^{-}=\frac{\sum_{t=2}^{\tau} y_{i, j, t}}{\sum_{t=2}^{\tau} x_{i, j, t}}
$$

Finally, the regular prices and price promotions ${ }^{2}$ enable us to compute the magnitude and the frequencies of the promotions as:

$$
F_{i, j}=\frac{\sum_{t=2}^{\tau} p_{i, j, t}}{\sum_{t=2}^{\tau} x_{i, j, t}}
$$

where the frequency of price promotions in the selected period for each brand $i$ in any outlet $j$ is expressed as the total number of promotions $p_{i, j}$ over the total price quotes present for brand $i$ in any outlet $j$.

\section{Results}

Table $1^{3}$ reports, respectively, average regular price, frequency, and size of price promotions and price changes (in the case of regular price the implicit price duration is included) for the selected pasta national and private label brands sold by modern retailers in Italy from 2011 to 2013. Tables 2-6 (reported in the Appendix) show the same statistics and data processing referring to the selected Italian macro-regions (north-east, north-west, center, south, and islands).

The average regular prices allow us to comprehend the Italian pasta market structure. At the highest segment we find three national brands (Garofalo, De Cecco, and Voiello) with an average price ranging from 1.99 to 2.34 euros; the rest of national brands ${ }^{4}$ included in our dataset are sold at prices that range from 1.82 to 1.23 euros. Prices of the three selected private labels are between 1 and 1.20 euros.

At national level, the highest frequency of price promotions is shown by national brands placed in the highest segment, except Voiello, Divella, and Barilla, the leader in the Italian pasta market (Antitrust 2009). In percentage terms, the average size of price promotions ranges from $16.9 \%$ for Voiello to almost 30\% for Garofalo; a larger magnitude, in monetary terms, is shown by the latter and De Cecco. Results concerning price promotions show an interesting finding related to retailers' strategies: the private label products, which present regular prices lower than national pasta brands, are sold without promotions. These results are aligned with the theoretical model proposed by Agrawal (1996), who predicted that retailers will promote brands with strongly brand-loyal customers more often but with a smaller discount than weaker brands, while other theoretical models (e.g., Raju et al. 1990) and empirical analyses (Allender and Richards 2012; Empen et al. 2015) arrive at the reverse conclusion. This might be due to the relevance of pasta in retailers' strategies. Since pasta represents a strategic product for Italian consumers, retailers prefer strongly promoting national brands in order to attract a large share of customers to their outlets to stimulate other sales of more profitable goods.

Considering price promotions in the different Italian macro-regions (Tables 2-6), it is worth noting that in the southern regions, the frequency and the average size are decisively higher than in the rest of Italy. For instance, except for Voiello and Amato, the promotion frequency of the national brands in southern regions ranges from $63.4 \%$ to $96.8 \%$ of the selected weeks. In the other Italian regions the frequency of the discounts is decidedly lower. In the interpretation of this result, it might be useful to recall that in Southern Italy pasta consumption is more relevant than in other Italian areas (Cersosimo 2011).

2 A relevant limitation of this study is that regular prices and price promotions are analyzed separately, even if it would be useful to investigate how retailers simultaneously use them in their strategies.

3 We have investigated whether discounts and price increases and decreases are concentrated over specific seasons of the year. The results show that retailers adopt a similar strategy during the various months of the year, indicating the relevance of pasta sales in the different outlets, which is often considered by retailers as a loss leader product, sold at price below its market cost to stimulate other sales of more profitable goods (Chevalier et al. 2003).

4 In the Italian pasta market other national brands are present. However, they are sold only in specific macro-regional areas. 
Focusing on the frequency of price changes, expressed as the average duration of an uninterrupted sequence of unchanged price quotes in term of weeks, their direction, and size, some interesting trends emerge. At the national level, Voiello presents the highest "stickiness" of regular prices, with an average duration of unchanged prices of 4.4 weeks, while the other national brands range from 1.8 to 3.1 weeks. Prices for private labels, on average, are changed less frequently (approximately every 13 weeks). Considering the direction of price changes, the frequency of price increases of national pasta brands ranges from $10.5 \%$ (Voiello) to $27.7 \%$ (Amato), with an average of $19.6 \%$; for private labels, instead, the average percentage of price increase is lower (11.2\%), ranging from $2.5 \%$ to $17.1 \%$.

Price reductions for national brands are, on average, slightly less frequent than increases $(18.9 \%$ vs. 19.6\%); however, in the highest market segment, except Voiello, national brands reduce price less frequently. While the frequency of the direction change is asymmetric among national brands positioned in different market segments, the average magnitude is similar. Although price reductions for private labels are less frequent than price increases, their size is greater.

These results confirm that significantly higher retail price rigidity is found for private label products than for nationally branded products (Müller et al. 2006). A plausible explanation is that when national brands raise their prices, they lose fewer sales to private labels than private labels lose to national brands when private labels raise their prices (Sivakumar and Raj 1997).

Results for price rigidity in the Italian pasta market are highly heterogeneous across the five different macro-regions (Tables 2-6). In the north-east of Italy, retail prices are less "sticky", and at the same time, the tool of price promotion is employed less frequently. This may imply a sort of trade-off between regular prices and price promotions through which retailers alternatively implement the two strategies in the different areas. Moreover, focusing on different national brands it is worth noting that also in this case, retailers adopt different strategies in different areas. Among the key-factors influencing retailers in the pricing strategy, there are consumer preferences and brand loyalty to some national brands that might change across the targeted regional areas. Considering the relevance of pasta sales in the different outlets, retailers presumably know the two dimensions of brand loyalty (the number of loyal customers and the intensity of their loyalty) in the different areas and consequently adopt various pricing strategies, as found in other studies for other products (Empen et al. 2015). 
Table 1. Frequency, size, and implicit price duration of regular price changes and price promotions in Italy (2011-2013).

\begin{tabular}{|c|c|c|c|c|c|c|c|c|}
\hline \multirow{3}{*}{ Average Regular Price (1) } & \multirow{2}{*}{\multicolumn{3}{|c|}{ Price Promotions (2) }} & \multicolumn{5}{|c|}{ Price Changes (3) } \\
\hline & & & & \multicolumn{2}{|c|}{ Increases } & \multicolumn{2}{|c|}{ Decreases } & \multirow{2}{*}{$\begin{array}{c}\text { Rigidity } \\
\text { Implicit Price (week) }\end{array}$} \\
\hline & Frequency (\%) & Average Size $(€)$ & Average Size (\%) & Frequency (\%) & Average Magnitude ( $($ ) & Frequency (\%) & Average Magnitude (€) & \\
\hline 2.34 & 89.6 & 0.69 & 29.6 & 19.7 & 0.05 & 15.1 & 0.05 & 2.9 \\
\hline 2.31 & 99.5 & 0.48 & 20.6 & 21.8 & 0.04 & 17.8 & 0.04 & 2.5 \\
\hline 1.99 & 57.8 & 0.31 & 16.9 & 10.5 & 0.04 & 12.4 & 0.03 & 4.4 \\
\hline 1.82 & 21.1 & 0.34 & 18.5 & 16.9 & 0.06 & 15.6 & 0.07 & 3.1 \\
\hline 1.50 & 14.0 & 0.42 & 28.8 & 27.7 & 0.03 & 21.6 & 0.03 & 2.0 \\
\hline 1.55 & 95.5 & 0.29 & 18.0 & 16.3 & 0.02 & 18.9 & 0.02 & 2.8 \\
\hline 1.23 & 87.1 & 0.34 & 27.0 & 24.2 & 0.03 & 30.7 & 0.02 & 1.8 \\
\hline 1.02 & - & - & - & 2.5 & 0.02 & 0.9 & 0.03 & 30.8 \\
\hline 1.06 & - & - & - & 14.0 & 0.04 & 6.6 & 0.06 & 4.9 \\
\hline 1.19 & - & - & - & 17.1 & 0.08 & 15.1 & 0.08 & 3.1 \\
\hline 1.60 & 66.4 & 0.41 & 22.8 & 17.1 & 0.04 & 15.5 & 0.04 & 5.8 \\
\hline 1.82 & - & - & - & 19.6 & 0.04 & 18.9 & 0.04 & 2.8 \\
\hline 1.09 & - & - & - & 11.2 & 0.04 & 7.5 & 0.06 & 12.9 \\
\hline
\end{tabular}

Source: our elaboration from Ismea data. (1) Prices are expressed per kilogram on the package from $500 \mathrm{~g}$; (2) price promotion size is calculated as difference between price promotion and regular price; (3) we considered price change when it was higher than $1 \%$.

Table 2. Frequency, size, and implicit price duration of regular price changes and price promotions in North-West Italy (2011-2013).

\begin{tabular}{|c|c|c|c|c|c|c|c|c|c|}
\hline \multirow{3}{*}{ BRAND } & \multirow{3}{*}{ Average Regular Price (1) } & \multirow{2}{*}{\multicolumn{3}{|c|}{ Price Promotions (2) }} & \multicolumn{5}{|c|}{ Price Changes (3) } \\
\hline & & & & & \multicolumn{2}{|c|}{ Increases } & \multicolumn{2}{|c|}{ Decreases } & \multirow{2}{*}{$\begin{array}{c}\text { Rigidity } \\
\text { Implicit Price (week }\end{array}$} \\
\hline & & Frequency $(\%)$ & Average (€) & Average (\%) & Frequency (\%) & Average Magnitude (€) & Frequency (\%) & Average Magnitude (€) & \\
\hline Garofalo & 2.37 & 47.7 & 0.67 & 28.4 & 18.4 & 0.10 & 21.7 & 0.08 & 2.5 \\
\hline De Cecco & 2.29 & 42.9 & 0.55 & 23.7 & 30.7 & 0.08 & 20.3 & 0.10 & 2.0 \\
\hline $\begin{array}{l}\text { Voiello } \\
\text { V }\end{array}$ & 2.02 & 27.6 & 0.27 & 13.0 & 19.2 & 0.07 & 17.2 & 0.07 & 2.7 \\
\hline Agnesi & 1.86 & & & & 19.6 & 0.07 & 18.3 & 0.08 & 2.6 \\
\hline Amato & 1.63 & & & & 27.7 & 0.03 & 21.6 & 0.04 & 2.0 \\
\hline Barilla & 1.60 & 31.6 & 0.33 & 20.2 & 20.8 & 0.04 & 18.8 & 0.05 & 2.5 \\
\hline Divella & 1.48 & 21.6 & 0.39 & 26.5 & 25.7 & 0.08 & 24.3 & 0.08 & 2.0 \\
\hline Private Label 1 & - & & - & - & - & & - & - & - \\
\hline Private Label 2 & 1.06 & 0 & 0 & 0 & 9.5 & 0.07 & 8.0 & 0.09 & 5.7 \\
\hline Private Label 3 & & - & - & - & - & - & - & - & - \\
\hline
\end{tabular}


Table 2. Cont.

\begin{tabular}{|c|c|c|c|c|c|c|c|c|c|}
\hline \multirow{3}{*}{ BRAND } & \multirow{3}{*}{ Average Regular Price (1) } & \multirow{2}{*}{\multicolumn{3}{|c|}{ Price Promotions (2) }} & \multicolumn{5}{|c|}{ Price Changes (3) } \\
\hline & & & & & \multicolumn{2}{|c|}{ Increases } & \multicolumn{2}{|c|}{ Decreases } & \multirow{2}{*}{$\begin{array}{c}\text { Rigidity } \\
\text { Implicit Price (week }\end{array}$} \\
\hline & & Frequency $(\%)$ & Average (€) & Average (\%) & Frequency $(\%)$ & Average Magnitude (€) & Frequency $(\%)$ & Average Magnitude (€) & \\
\hline Average & 1.79 & 34.3 & 0.44 & 22.4 & 21.5 & 0.07 & 18.8 & 0.07 & 2.8 \\
\hline $\begin{array}{l}\text { Average National brands } \\
\text { Average Private label }\end{array}$ & $\begin{array}{l}1.89 \\
1.06\end{array}$ & - & $\begin{array}{l}- \\
-\end{array}$ & $\begin{array}{l}- \\
-\end{array}$ & $\begin{array}{c}23.2 \\
9.5\end{array}$ & $\begin{array}{l}0.07 \\
0.07\end{array}$ & $\begin{array}{l}20.3 \\
8.0\end{array}$ & $\begin{array}{l}0.07 \\
0.09\end{array}$ & $\begin{array}{l}2.3 \\
5.7\end{array}$ \\
\hline $\begin{array}{l}\text { (1) Prices are expressed per kilogram } \\
\text { on package from } 500 \text { grams } \\
\text { (2) Promotion size is calculated as } \\
\text { difference between price promotion } \\
\text { and regular price } \\
\text { (3) We considered price change when } \\
\text { it was higher than } 1 \%\end{array}$ & & & & & & & & & \\
\hline
\end{tabular}

Source: our elaboration from Ismea data. (1) Prices are expressed per kilogram on the package from $500 \mathrm{~g}$; (2) price promotion size is calculated as difference between price promotion and regular price; (3) we considered price change when it was higher than $1 \%$.

Table 3. Frequency, size, and implicit price duration of regular price changes and price promotions in North-East Italy (2011-2013).

\begin{tabular}{|c|c|c|c|c|c|c|c|c|c|}
\hline \multirow{3}{*}{ BRAND } & \multirow{3}{*}{ Average Regular Price (1) } & \multirow{2}{*}{\multicolumn{3}{|c|}{ Price Promotions (2) }} & \multicolumn{5}{|c|}{ Price Changes (3) } \\
\hline & & & & & \multicolumn{2}{|c|}{ Increases } & \multicolumn{2}{|c|}{ Decreases } & \multirow{2}{*}{$\begin{array}{c}\text { Rigidity } \\
\text { Implicit Price (week } \\
\end{array}$} \\
\hline & & Frequency (\%) & Average (€) & Average (\%) & Frequency $(\%)$ & Average Magnitude ( $(€)$ & Frequency $(\%)$ & Average Magnitude (€) & \\
\hline Garofalo & 2.35 & 25.0 & 0.85 & 36.1 & 23.9 & 0.13 & 25.8 & 0.11 & 2.0 \\
\hline De Cecco & 2.25 & 39.1 & 0.65 & 28.2 & 20.1 & 0.12 & 13.0 & 0.16 & 3.0 \\
\hline Voiello & 1.97 & 28.1 & 0.46 & 23.3 & 13.2 & 0.04 & 8.6 & 0.04 & 4.6 \\
\hline Agnesi & 1.96 & - & - & - & 5.2 & 0.09 & 3.3 & 0.20 & 11.8 \\
\hline Barilla & 1.57 & 42.6 & 0.42 & 26.9 & 7.1 & 0.03 & 10.4 & 0.02 & 5.7 \\
\hline Amato & 1.47 & - & - & - & 13.8 & 0.06 & 13.1 & 0.07 & 3.7 \\
\hline Divella & 1.42 & 16.3 & 0.58 & 40.8 & 28.3 & 0.13 & 23.0 & 0.16 & 1.9 \\
\hline Private Label 1 & 1.02 & - & - & - & 3.3 & 0.02 & 0 & 0.00 & 30.0 \\
\hline Private Label 2 & 1.06 & - & - & - & - & - & - & - & - \\
\hline Private Label 3 & - & - & - & - & - & - & - & - & - \\
\hline Average & 1.67 & 30.2 & 0.59 & 31.1 & 14.4 & 0.08 & 12.2 & 0.09 & 7.8 \\
\hline Average National brands & 1.86 & - & - & - & 15.9 & 0.09 & 13.9 & 0.11 & 4.7 \\
\hline Average Private label & 1.04 & - & - & - & 3.3 & 0.02 & 0.0 & 0.00 & 30.0 \\
\hline
\end{tabular}

Source: our elaboration from Ismea data. (1) Prices are expressed per kilogram on the package from $500 \mathrm{~g}$; (2) price promotion size is calculated as difference between price promotion and regular price; (3) we considered price change when it was higher than $1 \%$. 
Table 4. Frequency, size, and implicit price duration of regular price changes and price promotions in Central Italy (2011-2013).

\begin{tabular}{|c|c|c|c|c|c|c|c|c|c|}
\hline \multirow{3}{*}{ BRAND } & \multirow{3}{*}{ Average Regular Price (1) } & \multirow{2}{*}{\multicolumn{3}{|c|}{ Price Promotions (2) }} & \multicolumn{5}{|c|}{ Price Changes (3) } \\
\hline & & & & & \multicolumn{2}{|c|}{ Increases } & \multicolumn{2}{|c|}{ Decreases } & \multirow{2}{*}{$\begin{array}{c}\text { Rigidity } \\
\text { Implicit Price (week }\end{array}$} \\
\hline & & Frequency $(\%)$ & Average (€) & Average (\%) & Frequency $(\%)$ & Average Magnitude ( $€$ ) & Frequency (\%) & Average Magnitude (€) & \\
\hline Garofalo & 2.37 & 66.9 & 0.71 & 29.9 & 11.8 & 0.05 & 5.9 & 0.11 & 5.7 \\
\hline De Cecco & 2.31 & 73.9 & 0.62 & 26.8 & 17.8 & 0.03 & 11.2 & 0.04 & 3.5 \\
\hline Voiello & 1.91 & 33.1 & 0.34 & 17.6 & 10.4 & 0.07 & 7.1 & 0.07 & 5.7 \\
\hline Agnesi & 1.96 & & & & 2.6 & 0.18 & 3.2 & 0.20 & 17.0 \\
\hline Barilla & 1.51 & 70.8 & 0.28 & 18.3 & 26.5 & 0.04 & 20.0 & 0.04 & 2.2 \\
\hline Amato & 1.50 & & & & & & & & \\
\hline Divella & 1.35 & 35.3 & 0.34 & 24.5 & 20.0 & 0.03 & 16.1 & 0.04 & 2.8 \\
\hline Private Label 1 & 1.06 & - & - & - & 1.3 & 0.04 & 0 & 0.00 & 76.5 \\
\hline Private Label 2 & & - & - & - & - & - & - & - & \\
\hline Private Label 3 & 1.17 & - & - & - & 12.3 & 0.09 & 9.2 & 0.12 & 4.7 \\
\hline Average & 1.68 & 56.0 & 0.46 & 23.4 & 12.8 & 0.07 & 9.1 & 0.08 & 14.8 \\
\hline Average National brands & 1.84 & 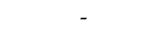 & - & - & 14.9 & 0.07 & 10.6 & 0.08 & 6.1 \\
\hline Average Private label & 1.12 & - & - & - & 6.8 & 0.06 & 4.6 & 0.06 & 40.6 \\
\hline
\end{tabular}

Source: our elaboration from Ismea data. (1) Prices are expressed per kilogram on the package from $500 \mathrm{~g}$; (2) price promotion size is calculated as difference between price promotion and regular price; (3) we considered price change when it was higher than $1 \%$.

Table 5. Frequency, size, and implicit price duration of regular price changes and price promotions in South Italy (2011-2013).

\begin{tabular}{|c|c|c|c|c|c|c|c|c|c|}
\hline \multirow{3}{*}{ BRAND } & \multirow{3}{*}{ Average Regular Price (1) } & \multirow{2}{*}{\multicolumn{3}{|c|}{ Price Promotions (2) }} & \multicolumn{5}{|c|}{ Price Changes (3) } \\
\hline & & & & & \multicolumn{2}{|c|}{ Increases } & \multicolumn{2}{|c|}{ Decreases } & \multirow[b]{2}{*}{ Implicit Price (week } \\
\hline & & Frequency $(\%)$ & Average $(\boldsymbol{\epsilon})$ & Average (\%) & Frequency (\%) & Average Magnitude ( $($ ) & Frequency $(\%)$ & Average Magnitude $(\epsilon)$ & \\
\hline Garofalo & 2.29 & 63.4 & 0.76 & 33.3 & 17.1 & 0.080 & 15.1 & 0.082 & 3.1 \\
\hline De Cecco & 2.33 & 96.8 & 0.48 & 20.3 & 20.8 & 0.069 & 16.9 & 0.077 & 2.7 \\
\hline Voiello & 2.04 & 11.1 & 0.54 & 26.3 & 13.8 & 0.075 & 15.1 & 0.067 & 3.5 \\
\hline \multicolumn{10}{|l|}{ Agnesi } \\
\hline Amato & 1.33 & 16.1 & 0.25 & 19.2 & 27.70 & 0.070 & 21.60 & 0.071 & 2.0 \\
\hline Barilla & 1.54 & 79.9 & 0.28 & 18.0 & 19.00 & 0.032 & 16.30 & 0.034 & 2.8 \\
\hline Divella & 1.11 & 83.8 & 0.27 & 24.5 & 12.4 & 0.041 & 13.7 & 0.034 & 3.8 \\
\hline Private Label 1 & 0.97 & - & - & - & 1.3 & 0.032 & 0.7 & 0.020 & 50.7 \\
\hline Private Label 2 & - & - & - & - & - & - & - & - & - \\
\hline Private Label 3 & - & - & - & - & - & - & - & - & - \\
\hline Average & 1.66 & 58.5 & 0.43 & 23.6 & 16.0 & 0.06 & 14.2 & 0.06 & 9.8 \\
\hline Average National brands & 1.77 & - & - & - & 18.5 & 0.06 & 16.5 & 0.06 & 3.0 \\
\hline Average Private label & 0.97 & - & - & - & 1.3 & 0.03 & 0.7 & 0.02 & 50.7 \\
\hline
\end{tabular}

Source: our elaboration from Ismea data. (1) Prices are expressed per kilogram on the package from $500 \mathrm{~g}$; (2) price promotion size is calculated as difference between price promotion and regular price; (3) we considered price change when it was higher than $1 \%$. 
Table 6. Frequency, size, and implicit price duration of regular price changes and price promotions in the Italian Islands (2011-2013).

\begin{tabular}{|c|c|c|c|c|c|c|c|c|c|}
\hline \multirow{3}{*}{ BRAND } & \multirow{3}{*}{ Average Regular Price (1) } & \multirow{2}{*}{\multicolumn{3}{|c|}{ Price Promotions (2) }} & \multicolumn{5}{|c|}{ Price Changes (3) } \\
\hline & & & & & \multicolumn{2}{|c|}{ Increases } & \multicolumn{2}{|c|}{ Decreases } & \multirow{2}{*}{$\begin{array}{c}\text { Rigidity } \\
\text { Implicit Price (week }\end{array}$} \\
\hline & & Frequency $(\%)$ & Average (€) & Average (\%) & Frequency (\%) & Average Magnitude (€) & Frequency (\%) & Average Magnitude (€) & \\
\hline Garofalo & 2.39 & 47.7 & 0.68 & 28.4 & 11.8 & 0.06 & 9.9 & 0.06 & 4.6 \\
\hline De Cecco & 2.42 & 32.7 & 0.62 & 25.5 & 17.1 & 0.07 & 19.7 & 0.06 & 2.7 \\
\hline Voiello & 2.08 & 8.6 & 0.27 & 13.3 & 14.6 & 0.04 & 11.3 & 0.05 & 3.9 \\
\hline Agnesi & 1.96 & - & - & - & 2.6 & 0.18 & 3.3 & 0.20 & 17.0 \\
\hline Amato & - & - & - & - & - & - & - & - & - \\
\hline Barilla & 1.61 & 22.1 & 0.14 & 8.9 & 2.6 & 0.03 & 3.4 & 0.03 & 13.9 \\
\hline Divella & 1.40 & 14.3 & 0.17 & 11.7 & 22.9 & 0.05 & 22.2 & 0.06 & 2.2 \\
\hline Private Label 1 & 1.08 & - & - & - & 2.6 & 0.04 & 0 & 0 & 38.2 \\
\hline Private Label 2 & - & - & - & - & - & - & - & - & - \\
\hline Private Label 3 & - & - & - & - & - & - & - & - & - \\
\hline Average & 1.85 & 25.1 & 0.38 & 17.6 & 10.6 & 0.07 & 10.0 & 0.06 & 11.8 \\
\hline Average National brands & 1.98 & - & - & - & 11.9 & 0.07 & 11.6 & 0.08 & 7.4 \\
\hline Average Private label & 1.08 & - & - & - & 2.6 & 0.04 & 0.0 & 0.00 & 38.2 \\
\hline
\end{tabular}

Source: our elaboration from Ismea data. (1) Prices are expressed per kilogram on the package from $500 \mathrm{~g}$; (2) price promotion size is calculated as difference between price promotion and regular price; (3) we considered price change when it was higher than $1 \%$. 


\section{Conclusions}

In the Italian agro-food industry, pasta represents a strategic product, since Italy has the peculiarity of being, at the same time, the main producer and consumer of pasta. In the last years, Italian food retailing has experienced some developments related to rising concentration levels, heterogeneous distribution along country of the different outlet categories, and an increase of products sold as private brand labels.

This work focuses on retailers' strategies in the Italian pasta market in terms of price rigidity and price promotions according to national and private labels brands and regional areas. The results show that at national level, national brands present lower price rigidity compared to private labels. This confirms the findings found in other studies (e.g., Müller et al. 2006), where a plausible explanation concerns the different effects, in terms of sales, of price cuts by private labels and leading national brands (Sivakumar and Raj 1997).

Considering the direction of price changes, different behavior emerges across market segments.

Specifically, prices increases of national brands situated at the highest market segment are more frequent than price reductions, while the opposite occurs for the other national brands. Another relevant result concerns the frequency and the magnitude of price promotions, which mainly regard the brands positioned in the higher market segment and the market leader. This might be due to the relevance of pasta in retailers' strategies. Since pasta represents a strategic product for Italian consumers, retailers prefer strongly promoting national brands in order to attract a large share of customers in their outlets to stimulate other sales of more profitable goods.

Finally, findings across the selected regional areas show how retailers adopt different pricing behavior in the different areas. Overall, the results seem to indicate that retailers' strategies for national pasta brands, in terms of price rigidity and price promotions, are completely different with respect to private label brands. Among the various national brands, retailers adopt a different approach by employing the tool of price promotion rather than intervening with price changes. Retailers presumably adopt different pricing strategies in the various Italians areas based on the different brand loyalty of customers in the pasta market.

Overall, these results seem to suggest that in order to identify the factors playing a relevant role in determining retailers' pricing strategies, it is crucial to take into consideration relevant product-specific and country-specific dynamics, rather than factors usually employed in literature (e.g., seasonality, inflation, and the use of psychological prices). In particular, in the pasta market a key-role is played by the degree of brand loyalty of Italian customers to the strong national brands. The results highlight a strong relationship between the degree of brand loyalty and the magnitude and frequency of price promotions and price rigidity. Another relevant factor affecting Italian consumers is the economic crisis that started in 2008. In fact, in the last years the economic crisis, which hardly damaged Italy, might have pushed a relevant share of consumers to take into consideration prices rather than product quality, implying an increase of private label product purchases. Moreover, in some cases pasta is considered as a loss leader product, sold at price below its market cost to stimulate other sales of more profitable goods. Furthermore, due to consumer preferences and cultural differences, pasta consumption is heterogeneous in the different Italian regional areas implying different price elasticity.

Additionally, retail industry characteristics (e.g., concentration, type of outlets, etc.) might have a relevant impact on price-setting behavior and on the differences in price levels within each country (Cornille and Langohr 2011).

Since the retail industry plays a key role in agro-food supply governance, further studies are needed to empirically assess how the different factors affect the retailers' strategies in the Italian pasta market, both in terms of price rigidity and price promotions.

Author Contributions: L.C. conceived the research idea, guided the research activities, built the case study analytical framework, conducted the data analysis and wrote Sections 1-4. A.S. provided support in building the case study and in the results interpretation, and wrote Section 5. 
Funding: This research received no external funding.

Conflicts of Interest: Page: 12The authors declare no conflict of interest.

\section{References}

Ailawadi, Kusum L., Jonathan P. Beauchamp, Naveen Donthu, Dinesh K. Gauri, and Venkathes Shankar. 2009. Communication and promotion decisions in retailing: A review and directions for future research. Journal of Retailing 85: 42-55. [CrossRef]

Allender, William J., and Timothy J. Richards. 2012. Brand loyalty and price promotion strategies: An empirical analysis. Journal of Retailing 88: 323-42. [CrossRef]

Agrawal, D. 1996. Effect of brand loyalty on advertising and trade promotions: A game theoretic analysis with empirical evidence. Marketing Science 15: 86-108. [CrossRef]

Antitrust. 2009. Autorità Garante della Concorrenza e del Mercato, Bolletino n ${ }^{\circ} 8$ del 16 marzo 2009.

Aucremanne, Luc, and Emmanuel Dhyne. 2004. How Frequently do Price Change? Empirical Evidence based on the Micro Data Underlying the Belgian CPI. Working Paper No. 331. Franfurt am Main: European Central Bank.

Banca d'Italia. 2012. di Eliana Viviano, Luciana Aimone Gigio, Emanuela Ciapanna, Daniele Coin, Fabrizio Colonna, Federica Lagna e Raffaele Santioni. In La grande Distribuzione Organizzata e L'industria Alimentare in Italia. Roma: Banca d'Italia.

Baudry, Le Bihan, and Tarrieu Sevestre. 2004. Price Rigidity in France-Evidence from Consumer Price Micro-Data. Working Paper No. 384. Franfurt am Main: European Central Bank.

Bils, Mark, and Peter J. Klenow. 2004. Some Evidence on the Importance of Sticky Prices. The Journal of Political Economy 112: 947-85. [CrossRef]

Bolton, Ruth, S. Venkatesh, and Detra Montoya. 2007. Recent Trends and Emerging Practices in Retail Pricing. In Retailing in the 21st Century: Current and Future Trends, 2nd ed. Edited by Manfred Kraft and Murali K. Mantrala. Berlin/Heidelberg: Springer.

Cacchiarelli, Luca, and Alessandro Sorrentino. 2018. Market power in food supply chain: Evidence from Italian pasta chain. British Food Journal 120: 2129-41. [CrossRef]

Cacchiarelli, Luca, Daniel Lass, and Alessandro Sorrentino. 2016. CAP reform and price transmission in the Italian pasta chain. Agribusiness 32: 482-97. [CrossRef]

Cacchiarelli, Luca, and Alessandro Sorrentino. 2015. Antitrust intervention and price transmission in pasta supply chain. Agricultural and Food Economics 4: 2. [CrossRef]

Cavicchioli, Daniele. 2018. Detecting Market Power along Food Supply Chains: Evidence and Methodological Insights from the Fluid Milk Sector in Italy. Agriculture 8: 191. [CrossRef]

Cersosimo, Domenico. 2011. I Consumi Alimentari: Evoluzione Strutturale, Nuove Tendenze, Risposte Alla Crisi. Roma: Edizioni Tellus.

Chevalier, Judith A., Anil K. Kashyap, and Peter E. Rossi. 2003. Why don't prices rise during periods of peak demand? Evidence from scanner data. American Economic Review 93: 15-37. [CrossRef]

Ciapanna, Emanuela, and Fabrizio Colonna. 2011. Retail Sector Concentration, Consumer Prices and SMEs Performance in Italy. Working Paper. Bologna: Bologna Centre for Law and Economics.

Cornille, D., and J. Langohr. 2011. The distributive trade sector and its impact on euro area prices. Economic Review 3: 35-52.

Dhyne, Emmanuel, Luis J. Alvarez, Hervé Le Bihan, Giovanni Veronese, Daniel Dias, Johannes Hoffmann, and Jouko Vilmunen. 2006. Price changes in the euro area and the United States: Some facts from individual consumer price data. The Journal of Economic Perspectives 20: 171-92. [CrossRef]

Dobson, Paul W., and Micheal Waterson. 1999. Retailer power: Recent developments and policy implications. Economic Policy 28: 133-64. [CrossRef]

Empen, Janine, Jeans P. Loy, and Christoph Weiss. 2015. Price promotions and brand loyalty: Empirical evidence for the German ready-to-eat cereal market. European Journal of Marketing 49: 736-59. [CrossRef]

Erdem, Tulin, Ying Zhao, and Ana Valenzuela. 2004. Performance of store brands: A cross-country analysis of consumer store-brand preferences, perceptions, and risk. Journal of Marketing Research 41: 86-100. [CrossRef]

Gauri, Dinesh K., Debabrata Talukdar, and Brian Ratchford. 2008. Empirical Investigation of the Impact of Loss Leader Promotion on Store and Category Performance in Grocery Industry. Working Paper. Syracuse: Syracuse University. 
Herrmann, Roland, and Anke Moeser. 2006. Do psychological prices contribute to price rigidity? Evidence from German scanner data on food brands. Agribusiness: An International Journal 22: 51-67. [CrossRef]

International Pasta Organization. 2012. International Pasta Organization Survey. The World Pasta Industry in 2011. Roma: International Pasta Organization.

Jing, Bing, and Zhong Wen. 2008. Finitely Loyal Customers, Switchers, and Equilibrium Price Promotion. Journal of Economics \& Management Strategy 17: 683-707.

Kantor, Linda S., Kathryn Lipton, Alden Manchester, and Victor Oliveira. 1997. Estimating and addressing America's food losses. Food Review 20: 2-12.

Koçaş, Cenk, and Jonathan D. Bohlmann. 2008. Segmented Switchers and Retailer Pricing Strategies. Journal of Marketing 72: 124-42. [CrossRef]

Lancaster, Kelvin. 1990. The economics of product variety: A survey. Marketing Science 9: 189-206. [CrossRef]

Messinger, Paul R., and Chakravarthi Narasimhan. 1997. A Model of Retail Formats Based on Consumers' Economizing on Shopping Time. Marketing Science 16: 1-23. [CrossRef]

Müller, George, Mark Bergen, Shantanu Dutta, and Daniel Levy. 2006. Private label price rigidity during holiday periods. Applied Economics Letters 13: 57-62. [CrossRef]

Narasimhan, Chakravarthi, Scott A. Neslin, and Subrata K. Sen. 1996. Promotional elasticities and category characteristics. Journal of Marketing 60: 17-30. [CrossRef]

OECD. 2014. Competition Issues in the Food Chain Industry. DAF/COMP(2014)16. Available online: http:/ / www. oecd.org/daf/competition/CompetitionIssuesintheFoodChainIndustry.pdf (accessed on 14 May 2016).

Perez-Mesa, Juan C., Emilio Galdeano-Gomez, and José A. Aznar-Sánchez. 2010. Retail price rigidity in perishable food products: A case study. Spanish Journal of Agricultural Research 8: 895-907. [CrossRef]

Raju, Jagmohan S., Venkataraman Srinivasan, and Rollie Lal. 1990. The Effects of Brand Loyalty on Competitive Price Promotional Strategies. Marketing Science 36: 276-304. [CrossRef]

Shankar, Vvenkatesh, and Ruth N. Bolton. 2004. An empirical analysis of determinants of retailer pricing strategy. Marketing Science 23: 28-49. [CrossRef]

Sivakumar, K Krishnasamy, and S. P. Raj. 1997. Quality tier competition: How price change influences brand choice and category choice. Journal of Marketing 61: 71-84. [CrossRef]

Sorrentino Alessandro, Carlo Russo, and Luca Cacchiarelli. 2018. Market power and bargaining power in the EU food supply chain: The role of Producer Organizations. New Medit, A Mediterranean Journal of Economics, Agriculture and Environment 17: 21-31. [CrossRef]

Unionalimentari. 2010. Senato della Repubblica. Commissione Straordinaria per la Verifica Dell'andamento Generale dei Prezzi al Consumo e per il Controllo della Trasparenza dei Mercati. Available online: http:/ / www.senato.it/documenti/repository/commissioni/controllo_prezzi/documenti_ acquisiti/UnionAlimentari_CONFAPI_03_02_10.pdf (accessed on 17 May 2016).

Verhelst, Benjamin, and Dirk Van den Poel. 2010. Price rigidity in Europe and the US: A Comparative Analysis Using Scanner Data (No. 10/684). Gent: Faculty of Economics and Business Administration, Ghent University.

Veronese, G., Silvia Fabiani, Angela Gattulli, and Roberto Sabbatini. 2005. Consumer Price Behaviour in Italy: Evidence from Micro CPI Data. Working Paper Series 449; Frankfurt am Main: European Central Bank.

Wang, Holly H., Na Hao, Qingjie Zhou, Micheal E. Wetzstein, and Yong Wang. 2019. Is fresh food shopping sticky to retail channels and online platforms? Evidence and implications in the digital era. Agribusiness 35: 6-19. [CrossRef]

(C) 2019 by the authors. Licensee MDPI, Basel, Switzerland. This article is an open access article distributed under the terms and conditions of the Creative Commons Attribution (CC BY) license (http://creativecommons.org/licenses/by/4.0/). 